\title{
Soil mites (Acari, Mesostigmata) from Szczeliniec Wielki in the Stolowe Mountains National Park (SW Poland)
}

\author{
JACEK KAMCZYC ${ }^{1}$ and DARIUSZ J. GWIAZDOWICZ \\ Poznań University of Life Sciences, Department of Forest Protection, Wojska Polskiego 28, 60-637 \\ Poznań, Poland; e-mail: ${ }^{1} j k a m @ u p . p o z n a n . p l$
}

(Received on 31 March 2009, Accepted on 21 July 2009)

\begin{abstract}
The species composition of mesostigmatid mites in the soil and leaf litter was studied on the Szczeliniec Wielki plateau, which is spatially isolated from similar rocky habitats. A total of 1080 soil samples were taken from June 2004 to September 2005. The samples, including the organic horizon from the herb layer and litter from rock cracks, were collected using steel cylinders (area $40 \mathrm{~cm}^{2}$, depth $0-10 \mathrm{~cm}$ ). They were generally dominated by Gamasellus montanus, Veigaia nemorensis, and Leptogamasus cristulifer. Rhodacaridae, Parasitidae and Veigaiidae were the most numerously represented families as regards to individuals. Among the 55 recorded mesostigmatid species, 13 species were new to the fauna of the Stołowe National Park. Thus the soil mesostigmatid fauna of the Szczeliniec Wielki plateau is generally poor and at an early stage of succession.
\end{abstract}

Keywords: mites, Acari, Mesostigmata, Stołowe Mountains National Park

\section{INTRODUCTION}

Biodiversity is usually described as species richness of a geographic area, with some reference to time. The diversity of plants and animals can be reduced by habitat fragmentation and spatial isolation. Moreover, spatial isolation and habitat fragmentation can affect ecosystem functioning (Schneider et al. 2007). Ecosystems with high species diversity are more resistant to disturbances and perturbations. Furthermore, ecosystem function may change unpredictably when diversity and/or species composition changes (Koehl er 1997).

Soil biodiversity can be characterized by the composition of soil animal communities, e.g. nematodes, enchytraeids, and mites. Mesostigmatid mites can be used as good bioindicators, because their distribution is worldwide and they are at the end of the mesofaunal energy chain (Čoja \& Bruckner 2006).

Moreover, biodiversity in spatially isolated areas should be better known in view of the anticipated impact of climate change upon soil biota and the potential consequences of ecosystem processes (Tayl or \& Wolters 2005). A very interesting habi- 
tat island is the Szczeliniec Wielki plateau in the Stołowe Mountains National Park. It is a high, isolated sandstone plateau with specific abiotic conditions and fauna. Low and stable temperature as well as high relative humidity create suitable conditions for arctic spiders (Bathypanthes eumenis) and rare collembolans (Schaeferia emucronata) (SMOLIS 2003).

Previously, several acarological projects in the Stołowe Mountains were conducted, leading to the discovery of over 81 species of mesostigmatid mites, including the rare relict species Iphidinychus gaieri (MichERDZIŃSKi 1969, BŁosZYK 1980, 1991, BŁoszyk \& Olszanowski 1984, Skorupski \& GoŁojuch 1996a, b, Skorupski et al. 1998, KaczmareK \& Marquardt 2006, Kamczyc 2006a, b, Gwiazdowicz, KaMCZYC 2009). However, those studies have been done on a small scale (single samples from diverse microhabitats) in various areas of the Stołowe Mountains. However, the fauna and communities of mesostigmatid mites inhabiting the soil on Szczeliniec Wielki have never been well recognized. Due to this, the goal of the present study was to analyse the species composition of soil mesostigmatid mites on the Szczeliniec Wielki plateau.

\section{STUDY AREA}

The Szczeliniec Wielki plateau is located in the Stołowe Mountains National Park. The Stołowe Mountains are the only table hills in Poland. They are located

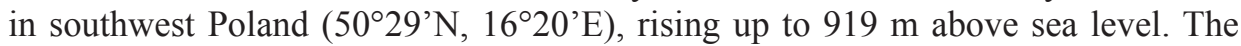
Szczeliniec Wielki plateau is bordered around by steep rock walls ending in wide boulder fields, and it is broken apart by deep cracks into a rock labyrinth. The base of the plateau and its summit are formed from sandstone, and its central part from marl. The herb layer is dominated by e.g. Vaccinium vitis-idaea, Vaccinium myrtillus, Dicranum scoparium, and Calluna vulgaris. The forest represents an early successional stage of the association Leucobryo-Pinetum. Scots pine Pinus sylvestris, common birch Betula pendula and Norway spruce Picea abies dominate in the tree layer on the plateau.

\section{MATERIAL AND METHODS}

A total of 1080 soil samples were taken from June 2004 to September 2005. The samples, including the organic horizon from the herb layer and litter from rock cracks, were collected using steel cylinders (area $40 \mathrm{~cm}^{2}$, depth $0-10 \mathrm{~cm}$ ). Mites were extracted using Berlese funnels with a mesh size of about $2 \mathrm{~mm}$. The soil cores were heated from above, with $40 \mathrm{~W}$ bulbs, and the extraction lasted 7 days. The organisms were collected in 70\% ethanol, mounted in permanent slides (using Hoyer's medium) and semi-permanent slides (using lactic acid), next counted, and identified. Juvenile specimens were marked as "juv." if not described in literature.

Indices of dominance $(D)$ (NiEDBAŁA et al. 1981) and constancy $(C)$ (KASPRZAK $\&$ NiEdBAŁA 1981) were used to characterise the mite community. Dominance classes were as follows: eudominants $(>10 \%$ of total catch); dominants $(5.01-10 \%)$; subdominants $(2.01-5.0 \%)$; residents $(1.01-2 \%)$, and subresidents $(<1 \%)$. For con- 
stancy, the following criteria were used: euconstants ( $>75 \%$ of samples); constants (50.01-75\%); subconstants (30.01-50\%); accessory species $(15.01-30 \%)$, and accidentals $(<5 \%)$.

\section{RESULTS}

Totally, 14813 individuals from the order Mesostigmata were found in the soil samples collected on the Szczeliniec Wielki plateau (Table 1). Analysis of the sample-based species accumulation curve showed that the number of collected samples is adequate, and further collection would not cause any significant increase in species number (Fig. 1). The collected individuals belonged to 49 mite species of 2 suborders: Gamasina (45 species; 13736 individuals) and Uropodina (4; 1077). No species from the orders Antennophorina, Microgynina as well as Sejina were found. The Parasitidae were a family represented by the largest number of species (12). Also the Laelapidae, Ascidae, and Veigaiidae were represented by several species $(7,6$, and 5 species, respectively). However, Rhodacaridae (4187 individuals), Parasitidae (4093), and Veigaiidae (3496) were the families with the most numerous individuals. Gamasellus montanus $(D=28.25 \%)$ and Veigaia nemorensis $(D=13.69 \%)$ were eudominants. Leptogamasus cristulifer $(D=6.89 \%)$ was classified as a dominant. Only 6 of the recorded 49 species occurred in $>30 \%$ samples (Table 1). Among them, Gamasellus montanus $(C=72 \%)$ was classified as the only constant species. Most of mite species occurred in less than $10 \%$ of samples.

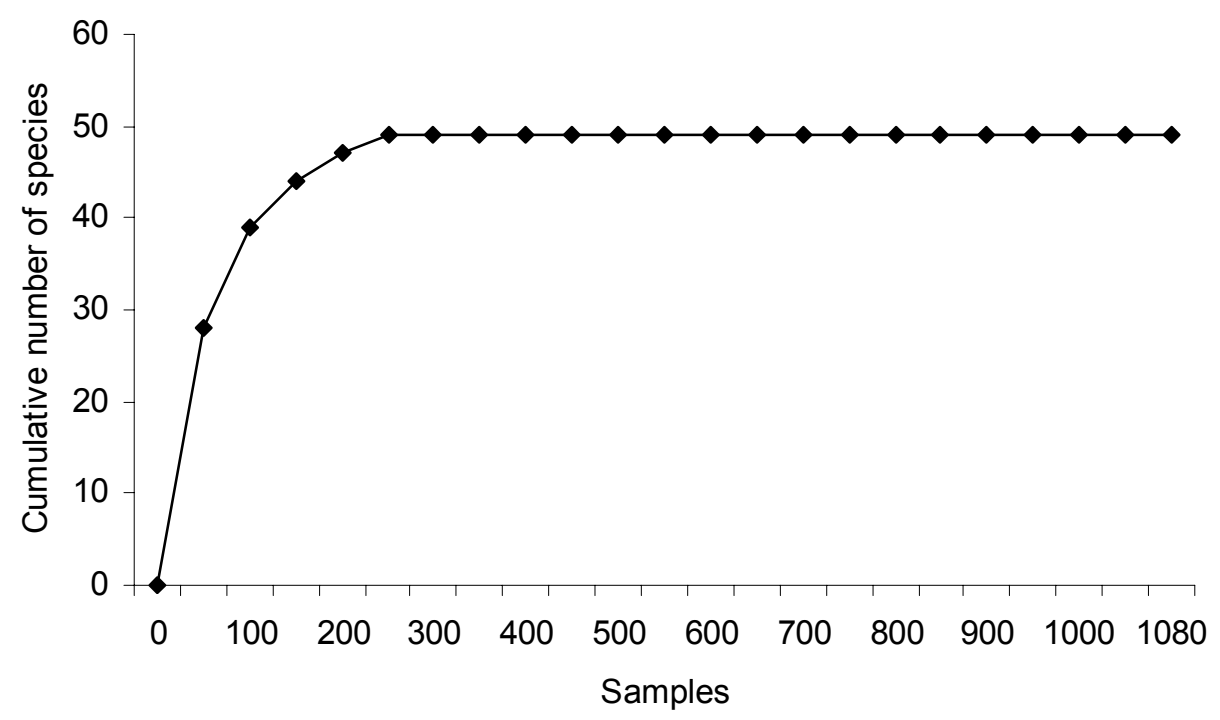

Fig. 1. Sample-based species accumulation curve for mesostigmatid mites occurring in the soil and leaf litter on the Szczeliniec Wielki plateau 
Table 1. List of mesostigmatid mites from the Szczeliniec Wielki plateau

\begin{tabular}{|c|c|c|c|c|}
\hline Species & Family & $\mathbf{N}$ & $\begin{array}{l}\text { Dominance } \\
(\%)\end{array}$ & $\begin{array}{c}\text { Constancy } \\
(\%)\end{array}$ \\
\hline \multicolumn{5}{|l|}{ Gamasina } \\
\hline Gamasellus montanus (Willmann, 1936) & $\mathrm{R}$ & 4184 & 28.25 & 72.22 \\
\hline Veigaia nemorensis (C.L. Koch, 1839) & $\mathrm{V}$ & 2029 & 13.70 & 46.11 \\
\hline $\begin{array}{l}\text { Leptogamasus cristulifer (Athias-Henriot, } \\
\text { 1967) }\end{array}$ & $\mathrm{P}$ & 1022 & 6.90 & 36.57 \\
\hline Leptogamasus sp. (juv.) & $\mathrm{P}$ & 995 & 6.72 & 37.13 \\
\hline Veigaia mollis Karg, 1971 & $\mathrm{~V}$ & 884 & 5.97 & 31.67 \\
\hline Leptogamasus obessus (Holzmann, 1955) & $\mathrm{P}$ & 764 & 5.16 & 30.28 \\
\hline Parazercon radiatus (Berlese, 1914) & & 679 & 4.58 & 16.85 \\
\hline $\begin{array}{l}\text { Paragamasus neoruncatellus (Schweizer, } \\
\text { 1961) }\end{array}$ & $\mathrm{P}$ & 427 & 2.88 & 22.96 \\
\hline Geholaspis pauperior Berlese, 1918 & & 425 & 2.87 & 5.93 \\
\hline Veigaia cervus (Kramer, 1876) & V & 392 & 2.65 & 24.07 \\
\hline Pachylaelaps furcifer Oudemans, 1903 & & 314 & 2.12 & 17.59 \\
\hline Paragamasus sp. (juv.) & $\mathrm{P}$ & 269 & 1.82 & 14.17 \\
\hline Amblyseius sp. & & 233 & 1.57 & 10.00 \\
\hline $\begin{array}{l}\text { Paragamasus holzmannae (Micherdziński, } \\
\text { 1969) }\end{array}$ & $\mathrm{P}$ & 226 & 1.53 & 13.61 \\
\hline Veigaia kochi (Trägírdh, 1901) & V & 178 & 1.20 & 10.46 \\
\hline Pergamasus barbarus (Berlese, 1904) & $\mathrm{P}$ & 134 & 0.90 & 8.43 \\
\hline Pergamasus (Thenargamasus) sp. (juv.) & $\mathrm{P}$ & 77 & 0.52 & 5.09 \\
\hline Hypoaspis procera Karg, 1965 & $\mathrm{~L}$ & 67 & 0.45 & 3.89 \\
\hline Porrhostaspis lunulata Müller, 1859 & $\mathrm{P}$ & 63 & 0.43 & 1.85 \\
\hline Hypoaspis vacua (Michael, 1891) & $\mathrm{L}$ & 62 & 0.42 & 1.67 \\
\hline Eviphis ostrinus (C.L. Koch, 1836) & & 60 & 0.41 & 3.89 \\
\hline Pergamasus mediocris Berlese, 1904 & $P$ & 58 & 0.39 & 4.72 \\
\hline Hypoaspis isotricha (Kolenati, 1858) & $\mathrm{L}$ & 20 & 0.14 & 1.57 \\
\hline Ololaelaps veneta $($ Berlese, 1903) & $\mathrm{L}$ & 15 & 0.10 & 0.83 \\
\hline Lasioseius lawrencei Evans, 1958 & A & 14 & 0.09 & 1.30 \\
\hline Paragamasus insertus (Micherdziński, 1969) & $\mathrm{P}$ & 13 & 0.09 & 0.65 \\
\hline Veigaia transisalae (Oudemans, 1902) & $\mathrm{V}$ & 13 & 0.09 & 0.65 \\
\hline Vulgarogamasus kraepelini (Berlese, 1904) & $\mathrm{P}$ & 13 & 0.09 & 0.74 \\
\hline Arctoseius semiscissus (Berlese, 1892) & A & 12 & 0.08 & 1.02 \\
\hline
\end{tabular}


Pergamasus (Pergamasus) sp. (juv.)

$\begin{array}{llll} & 12 & 0.08 & 1.02 \\ & 12 & 0.08 & 0.74 \\ \mathrm{P} & 11 & 0.07 & 0.83 \\ & 10 & 0.07 & 0.74 \\ \mathrm{P} & 8 & 0.05 & 0.46 \\ & 7 & 0.05 & 0.56 \\ \mathrm{~L} & 6 & 0.04 & 0.46 \\ \mathrm{~A} & 5 & 0.03 & 0.46\end{array}$

Kamczyc, 2009

Arctoseius brevichelis Karg, 1969

$\begin{array}{llll}\text { A } & 3 & 0.02 & 0.19\end{array}$

Hypoaspis oblonga (Halbert, 1915)

L 3

0.19

Asca aphidioides (Linnaeus, 1758)

A

Asca bicornis (Canestrini et Franzago, 1887)

A 2

0.19

Geholaspis longispinosus (Kramer, 1876)

Hypoaspis praesternalis Willmann, 1949

L

Zercon fageticola Halašková, 1969

Dendrolaelaps arvicolus (Leitner, 1949)

Epicrius sp.

Paragamasus runcatellus (Berlese, 1903)

Rhodacarus aequalis Karg, 1971

Rhodacarus mandibularis Berlese, 1921

Rhodacarus sp.

0.02

0.19

2

0.09

0.01

(1.09

0.01

0.09

2

0.19

1

0.01

0.09

1

0.01

0.09

P 1

0.01

0.09

R 1

0.01

0.09

R 1

0.01

0.09

R

0.01

0.09

Zercon sp.

0.01

0.09

\section{Uropodina}

Trachytes aegrota (C.L. Koch, 1841)

juv. $=$ juvenile; $\mathrm{N}=$ number of individuals. Families: $\mathrm{A}=$ Ascidae $\mathrm{L}=$ Laelapidae, $\mathrm{P}=$ Parasitidae, $\mathrm{R}=$ Rhodacaridae, $\mathrm{V}=$ Veigaiidae

Thanks to this study, the list of known mesostigmatid mites for the Stołowe Mountains National Park has been supplemented with 13 species: Arctoseius brevichelis, Asca aphidioides, A. bicornis, Dendrolaelaps arvicolus, Epicrius resinae, Hypoaspis isotricha, H. praesternalis, Ololaelaps veneta, Paragamasus holzmannae, Rhodacarus mandibularis, Trichouropoda ovalis, Urodiaspis tecta and Veigaia transisalae. No relict mite species was found in this study. 


\section{CONCLUSIONS}

1. The soil environment of the Szczeliniec Wielki plateau is generally poor in Mesostigmata. Only 49 species of mites were found in this study.

2. The acarofauna of the Szczeliniec Wielki plateau is characterized by the presence of rare mites (e.g. A. wisniewskii, L. cristulifer, V. mollis).

3. Mite community of the study area is at an early stage of succession, reflected in the large number of predators from the families Parasitidae and Veigaiidae.

Acknowledgements. We would like to thank Emilia Pers-Kamczyc and RadosŁaw Rakowski for their extensive help during sample collection and for enthusiastic assistance in mite determination.

\section{REFERENCES}

BŁoszyk J. 1980. Rodzaj Trachytes Michael, 1894 (Acari, Mesostigmata) w Polsce. Pr. Kom. Nauk Biol. PTPN. 54: 5-52.

BŁoszyK J. 1991. Stan zbadania fauny Uropodina (Acari: Anactinotrichida) parków narodowych w Polsce. Parki nar. Rez. przyr. 15: 47-62.

BŁoszyK J., Olszanowski Z. 1984. Uroseius (Apionoseius) gaieri (Schweitzer, 1961) nowy dla fauny Polski gatunek roztocza (Acari, Uropodina). Przegl. Zool. 28: 491-496.

ČoJa T., BRUCKNER A. 2003. Soil microhabitat diversity of a temperate Norway spruce (Picea abies) forest does not influence the community composition of gamasid mites (Gamasida, Acari). Eur. J. Soil. Biol. 39: 79-84.

Gwiazdowicz D.J., Kamczyc J. 2009. Arctoseius wisniewskii sp. nov. (Acari: Ascidae) from Poland. Ann. Zool. 59: 119-123.

Kaczmarek S., Marquardt T. 2006. Parasitidae (Acari: Gamasida) of the Stołowe Mts. National Park. Biol. Lett. 43: 179-185.

KAMCZYC J. 2006a. Microhabitat preferences of Veigaia mollis Karg, 1971 in the mountain reserve „Szczeliniec Wielki”. Biol. Lett. 43: 193-195.

KAmcZYC J. 2006b. The population structure of Gamasellus montanus (Willmann, 1936) in three different forest groups in the Szczeliniec Wielki nature reserve. Abh. Ber. Naturkundesmus. 78: 11-17.

KasprzaK K., Niedbata W. 1981. Wskaźniki biocenotyczne stosowane przy porządkowaniu i analizie danych w badaniach ilościowych. In: Metody stosowane w zoologii gleby (Górny M., Grüm L., Eds). pp. 396-416, Wyd. PWN, Warszawa.

KoeHLER H.H. 1997. Mesostigmata (Gamasina, Uropodina), efficient predators in agroecosystems. Agriculture, Ecosystems and Environment. 62: 105-117

MicherdZińSKi W. 1969. Die Familie Parasitidae Oudemans, 1901 (Acarina, Mesostigmata). PWN, Kraków.

NiedbaŁa W., BŁaszak Cz., BŁoszyk J., Kaliszewski M., Każmierski A. 1981. Roztocze (Acari). Fragm. Faun. 9: 105-155.

Schneider K., Scheu S., Maraun M. 2007. Microarthropod density and diversity respond little to spatial isolation. Basic Appl. Ecol. 8: 26-35.

Skorupski M., Ciechanowicz A., GoŁoJuch P., Święcioch J. 1998. Mites of the Family Parasitidae (Acari, Mesostigmata) of the Drawno National Park, Góry Stołowe National Park, Magura National Park. Zesz. Nauk. Akademia Techniczno-Rolnicza (Bydgoszcz), 214, Ochrona środowiska. 2: 289-290. 
Skorupski M., GoŁoJuch P. 1996a. Roztocze (Acari, Mesostigmata) wybranych mikrośrodowisk Parku Narodowego Gór Stołowych. Parki nar. Rez. przyr. 15: 73-79.

Skorupski M., GoŁoJuch P. 1996b. Wstępne wyniki badań nad roztoczami z rzędu Mesostigmata (Acari) Parku Narodowego Gór Stołowych. Sympozjum naukowe „Środowisko przyrodnicze Parku narodowego Gór Stołowych” 11-13 October, Kudowa Zdrój. pp. 185-188.

Smolis A. 2003. Skoczogonki (Collembola) Parku Narodowego Gór Stołowych. Szczeliniec, Wyd. Parku Narodowego Gór Stołowych. Kudowa Zdrój: 63-73.

TAYlor A.R., Wolters V. 2005. Responses of Oribatid mite communities to summer drought: The influence of litter type and quality. Soil Biol. Biochem. pp. 2117-2130. 